Suska Journal of Mathematics Education

Vol.2, No. 1, 2016, Hal. 67 - 75

\title{
Kajian Pengembangan Pembelajaran Model Active Knowledge Sharing dan Team Asissted Individualization dalam Mendukung Andragogi untuk Meningkatkan Hasil Belajar Siswa SMA di Propinsi Riau
}

\author{
Zulkifli Nelson, Musa Thahir, Khusnal Marzuqo \\ Program Studi Pendidikan Matematika, UIN Suska Riau \\ Email: kamp_guntung@yahoo.co.id
}

\begin{abstract}
ABSTRAK. Pemanfatan terhadap teknologi internet untuk pembelajaran di Indonesia sudah dimulai pada tahun 1996. Kondisi tersebut, kemudian disikapi oleh Direktorat Jenderal Manajemen Pendidikan Dasar dan Menengah (Ditjen Mandikdasmen) Departemen Pendidikan Nasional (Depdiknas) dengan menerapkan proses belajar mengajar berbasis teknologi informasi dan komunikasi (TIK) kepada siswa SMP. Bahkan pada tahun 2009 telah tersambung 18000 sambungan internet tercapai pada 27 Desember 2009. Akan tetapi, berdasarkan hasil penelitian Heru Suhartanto pada tahun 2009 pada sekolah-sekolah di Provinsi Riau, bahwa perkembangan Learning Management System (misalnya Moodle) dan situs tersebut mempunyai lebih dari sepuluh mata pelajaran yang dipraktekkan namun hanya ada satu sekolah yang memanfaatkan perkembangan tersebut. Kata kunci : model active knowledge sharing, team assisted individualization, hasil belajar.
\end{abstract}

\section{PENDAHULUAN}

Dewasa ini, teknologi informasi sudah menjadi tren atau kecendrungan sebagai salah satu media pembelajaran bagi siswa. Bahkan pemanfatan terhadap teknologi internet untuk pembelajaran di Indonesia sudah dimulai pada tahun 1996. Suara pembaharuan (2009) memberitakan bahwa kondisi tersebut, kemudian 
disikapi oleh Direktorat Jenderal Manajemen Pendidikan Dasar dan Menengah (Ditjen Mandikdasmen) Departemen Pendidikan Nasional (Depdiknas) dengan menerapkan proses belajar mengajar berbasis teknologi informasi dan komunikasi (TIK) kepada siswa SMP. Bahkan pada tahun 2009 telah tersambung 18000 sambungan internet tercapai pada 27 Desember 2009 (Sari, 2010). Akan tetapi, berdasarkan hasil penelitian Heru Suhartanto pada tahun 2009 pada sekolah-sekolah di Provinsi Riau, bahwa perkembangan Learning Management System (misalnya Moodle) dan situs tersebut mempunyai lebih dari sepuluh mata pelajaran yang dipraktekkan, hanya ada satu sekolah yang mengikutinya (Suhartanto, 2010: 80-81).

Hal ini diperkuat oleh pendapat Bullen dan Beam (Soekartawi,2003), yang menyatakan bahwa kelemahan penggunaan internet dalam belajar selama ini adalah : 1) Kurangnya interaksi antara guru dan siswa atau bahkan antar siswa itu sendiri. Kurangnya interaksi ini bisa memperlambat terbentuknya values dalam proses belajar dan mengajar; 2) Kecenderungan mengabaikan aspek akademik atau aspek sosial dan sebaliknya mendorong tumbuhnya aspek bisnis/komersial; 3) Proses belajar dan mengajarnya cenderung ke arah pelatihan daripada pendidikan; 4) Berubahnya peran guru dari yang semula menguasai teknik pembelajaran konvensional, kini juga dituntut mengetahui teknik pembelajaran yang menggunakan ICT; 5) Siswa yang tidak mempunyai motivasi belajar yang tinggi cenderung gagal.

Oleh karena itu, dibutuhkan sistem pembelajaran aktif pada proses pembelajaran yang berbasis pada IT tersebut. Pembelajaran ini, tidak sekedar menyajikan materi pelajaran ke dalam internet tetapi mempertimbangkan secara logis dan senantiasa memegang prinsip pembelajaran. Begitu pula desain pengembangan yang sederhana, personal, cepat, serta unsur hiburan akan menjadikan peserta didik betah belajar di depan internet seolah-olah mereka belajar di dalam kelas (Kodijat, 2001).

Pembelajaran aktif didesain untuk menghidupkan kelas dengan suasana belajar yang menyenangkan serta melibatkan gerak fisik maupun mental siswa. Keterlibatan ini akan meningkatkan partisipasi yang pada akhirnya akan meningkatkan hasil belajar siswa. Strategi pembelajaran aktif dapat digunakan untuk meningkatkan aktivitas belajar siswa. Salah satu bentuk pembelajaran aktif ini adalah Cooperative Learning, pembelajaran kooperatif. Sementara diantara tipe pembelajaran kooperatif adalah active knowledge sharing dan Team Assisted Individualization (TAI).

Strategi active knowledge sharing adalah suatu pembelajaran yang dapat membawa peserta didik siap menerima materi dengan cepat. Strategi pembelajaran ini didasarkan pada mengajukan pertanyaan yang berkaitan dengan materi kepada peserta didik dan mendapat tanggapan dari siswa. Bila strategi ini dilaksanakan, kemungkinan besar semua siswa secara aktif berpartisipasi dan mengevaluasi kinerja mereka. Active knowledge sharing (saling tukar pengetahuan) merupakan salah satu strategi yang dapat membawa peserta didik untuk siap belajar materi 
pelajaran dengan cepat. Strategi ini dapat digunakan untuk melihat kemampuan peserta didik disamping untuk membentuk kerja sama tim. Strategi ini dapat dilakukan pada hampir semua mata pelajaran (Zaini, 2008: 22).

Sementara Team Assisted Individualization adalah model pembelajaran individual dibantu kelompok atau tim. Dalam penggunaan tim belajar yang terdiri dari 4-5 anggota kelompok yang berkemampuan bervariasi. Team Assisted Individualization menggabungkan pembelajaran kooperatif dengan pembelajaran individual (Slavin, 2008: 195). Team Assisted Individualization dirancang untuk menyelesaikan masalah-masalah teoritis dan praktis dari sistem pengajaran individual (Slavin, 2008: 197).

Penelitian ini dirancang dengan menggabungkan antara pembelajaran kooperatif active knowledge sharing dan Team Assisted Individualization (TAI) dengan teknologi informasi. Model ini kemudian disebut dengan Hybrid Cooperative Learning, yaitu sebuah model pembelajaran yang mengaktifkan siswa secara individual (Team Assisted Individualization), sekaligus mengaktifkan siswa dengan saling tukar pengetahuan (Knowledge Sharing) yang berbasis pada teknologi informasi atau internet.

Konsep pembelajaran tersebut, setidaknya sudah menjadi bahan kajian yang menarik dan menunjukkan hasil yang lebih baik dibandingkan dengan metode lainnya. Misalnya, hasil penelitian yang dilakukan Blair F. Henley (2009), dengan menerapkan kedua metode tersebut dalam bentuk e-learning dalam pembelajaran di Tennessee High School, dapat meningkatkan hasil belajar siswa. Sementara itu penelitian Allison (2010), menyatakan bahwa pemahaman siswa terhadap materi pelajaran lebih baik, dengan menggunakan penggabungan metode tradisional dan $e$ learning (Hybrid Coperative Learning) dibanding metode tradisional serta $e$ learning saja dimana terdapat indikasi peningkatan pencapaian siswa dalam hasil pembelajaran dihampir semua mata pelajaran. Nikolaos et,al (2011) juga menyimpulkan hal yang sama bahwa pencapaian hasil pembelajaran lebih baik menggunakan metode Hybrid Coperative Learning dibandingkan metode tradisional. Begitu juga penelitian yang dilakukan Fan-Ray Kuo (2012) di SMA urban public school in southern Taiwan menyimpulkan bahwa metode Hybrid Coperative Learning memberikan pencapaian hasil belajar siswa lebih baik karena siswa lebih mudah untuk mengakses materi pembelajaran yang tepat di web dibanding sebelumnya dimana mereka mencari materi tanpa petunjuk guru.

Konsep ini, sangat mendukung konsep pendidikan Andragogi, yaitu sebuah konsep pendidikan yang menjadikan seorang guru tidak hanya berperan sebagai pendidik, pusat pengetahuan, penyelesain masalah dan sebagainya, akan tetapi berperan sebagai fasilitator. Seorang guru berfungsi lebih mengajak warga belajar menghadapi, menganalisa, serta mencari alternatif pemecahan suatu masalah. Oleh karena itu, fasilitator harus mampu memancing partisipasi peserta didik demi menghilangkan silence cultur, budaya bisu (meminjam istilah Freire), sehingga 
peserta didik dapat berintegrasi dan tidak hanya beradaptasi dengan lingkungan belajar (Freire, 1984: 4).

Berdasarkan hal tersebut di atas, maka penelitian ini akan membahas pada bagamaimana membuat pemodelan pembelajaran yang berbasis e-learning dengan menggabungkan Team Assisted Individualization dan Active Knowledge Sharing di Propinsi Riau.

\section{METODE PENELITIAN}

Penelitian ini menggunakan penelitian eksperimen. Bentuk eksperimen dalam penelitian ini adalah true experimental design. Metode yang digunakan adalah metode eksperimen, yaitu prosedur untuk menyelidiki hubungan sebab akibat dengan menempatkan obyek secara acak ke dalam kelompok-kelompok dimana satu atau dua variabel independen dimanipulasi.

Populasi dalam penelitian pada dasarnya adalah seluruh siswa SMA di Riau. Namun, karena luasnya wilayah dan banyaknya jumlah populasi maka sampel akan diambil menurut sampel wilayah yakni akan diambil dua sekolah SMA I di wilayah perkotaan dan kota sedang/kota kabupaten, yang selanjutnya disebut semi kota. Untuk wilayah perkotaan dalam hal ini akan diambil sampel dari SMA di kota Pekanbaru dan kota Dumai. Sedangkan untuk mewakili wilayah yang dikategorikan semi kota, diambil sampel dari SMA di Tembilahan Hulu dan Siak yang sekolahnya memiliki kemudahan akses internet dan memiliki lingkungan kehidupan yang tidak sulit mendapatkan akses ke internet. Dalam mendapatkan sampel untuk kelompok masing-masing treatment dan control di setiap sekolah yang terpilih sesuai sampel wilayah, maka akan dilakukan cluster sampling dari jumlah kelas yang ada di sekolah tersebut.

Untuk memperoleh data primer dari lapangan, sesuai dengan desain penelitiannya, maka digunakan tes untuk mengukur hasil belajar siswa baik dari masing-masing kelompok treatment maupun kelompok control. Sedangkan untuk memperoleh kepastian data tentang tepatnya perlakuan pada eksperimen akan digunakan teknik observasi dimana peneliti akan menyiapkan form observasi yang akan digunakan pada penelitian eksperimen tersebut.Sedangkan untuk memperoleh data-data sekunder seperti data karakteristik siswa dan sekolah yang diteliti akan digunakan teknik dokumentasi dan wawancara. Teknik ini hanya digunakan untuk memperoleh gambaran umum teori dan lokasi serta subjek yang diteliti.Setelah masing-masing data terkumpul dan ditabulasikan, maka data akan dianalisis dengan menggunakan analisa statistic parametric dengan menggunakan uji t dan ANOVA dengan menggunakan bantuan Program SPSS Versi 18.00 Sebelum melakukan uji ANOVA terlebih dahulu harus memenuhi beberapa persyaratan antara lain: distribusi data harus normal, setiap populasi hendaknya berasal dari populasi yang sama dengan variansi yang sama pula, dan pengambilan sampel dilakukan secara random (acak) (Hartono, 2010: 236). 


\section{HASIL PENELITIAN DAN PEMBAHASAN Hasil Penelitian}

1. Aktivitas Belajar Siswa

Secara umum pelaksanaan pembelajaran matematika dan sosiologi dengan Hybrid Learning melalui Moodle telah berjalan dengan baik. Jika dilihat secara keseluruhan pertemuan, aktivitas guru cenderung meningkat walaupun terkadang mengalami penurunan. Aktivitas siswa selama proses pembelajaran juga berjalan dengan baik. Ini terlihat dari rata-rata nilai yang diperoleh terhadap penilaian sikap siswa selama proses pembelajaran dengan Hybrid Learning melalui Moodle. Dilihat dari proses pembelajaran yang telah dilakukan dalam penelitian tersebut, dibandingkan dengan pembelajaran konvensional, pembelajaran dengan Hybrid Learning melalui Moodle menunjukkan peran yang berarti dalam meningkatkan hasil belajar siswa pada mata pelajaran matematika dan sosiologi.

Berdasarkan hasil angket, pembelajaran matematika dan sosiologi dengan Hybrid Learning melalui Moodle mampu menciptakan suasana belajar yang aktif dan menyenangkan. Suasana belajar ini dapat menyebabkan interaksi aktif antar siswa, siswa bekerja sama dalam proses pembelajaran untuk menemukan konsepkonsep matematika dan sosiologi yang nantinya menjadi pengetahuan yang mereka miliki. Melalui arahan dan bimbingan dari guru, siswa yang mengalami kesulitan dalam melakukan aktivitas pembelajaran akan segera dapat mengatasi masalahnya tanpa berhenti pada langkah tertentu yang membuatnya enggan melanjutkan pembelajaran. Selain itu, dengan adanya kelompok belajar, siswa pandai dapat membantu siswa yang kurang pandai sehingga terjalin kerjasama yang baik dalam pembelajaran.

\section{Sikap Belajar Siswa}

Siswa yang menjadi subjek pada penelitian ini secara umum mempunyai sikap positif terhadap pembelajaran matematika dan sosiologi. Sikap ini dipengaruhi oleh cara yang dipilih guru dalam memberikan pelajaran. Demikian juga sikap siswa terhadap pembelajaran matematika dan sosiologi dengan Hybrid Learning melalui Moodle. Dari jawaban siswa dapat diketahui bahwa pembelajaran matematika dan sosiologi dengan Hybrid Learning melalui Moodle memotivasi siswa dalam belajar sangat tinggi, sehingga mereka mau bekerja keras dalam menyelesaikan tugas yang diberikan. Sikap positif siswa ini merupakan awal yang baik dalam menerapkan Hybrid Learning melalui Moodle untuk meningkatkan pemahaman konsep dan kemampuan penalaran matematik siswa. Sejalan dengan pendapat Djadir (Nirmala, 2009) sikap positif terhadap matematika perlu diperhatikan karena berkorelasi positif dengan prestasi belajar matematika. Siswa yang menyukai matematika, prestasinya cenderung tinggi dan sebaliknya siswa yang tidak menyukai matematika prestasinya cenderung rendah. Disamping itu Berlin dan Hillen (Nirmala, 2009) menyatakan bahwa sikap positif akan menjadi langkah awal untuk menuju kepada lingkungan yang efektif. 
Pembelajaran matematika dan sosiologi dengan Hybrid Learning melalui Moodle dapat memberikan sumbangan dalam mengembangkan pemahamanmatematika dan sosiologi siswa dibanding dengan pembelajaran konvensional. Hal ini dapat diketahui dari jawaban siswa yang menyatakan lebih menyenangi cara belajar dengan Hybrid Learning melalui Moodle dan mereka merasa terbantu untuk berpikir kritis. Dengan demikian pembelajaran matematika dan sosiologi dengan Hybrid Learning melalui Moodle ini dapat mendukung fungsi matematika yang disebut Suherman, dkk (2001) yaitu sebagai wahana pembentukan berpikir kritis, sistematis, logis, kreatif dan mampu bekerja sama.

\section{Hasil Belajar Siswa}

Berdasarkan hasil penelitian yang diperoleh terlihat bahwa hasil belajar siswa yang menggunakan pembelajaran dengan Hybrid Learning melalui Moodle mengalami peningkatan yang lebih baik dibanding siswa yang pembelajarannya secara konvensional. Hal tersebut sesuai dengan hasil uji beda yang menyimpulkan bahwa hasil belajar antara kelompok eksperimen dan kontrol terdapat perbedaan setelah diberi perlakuan. Kemudian setelah dilakukan pembelajaran dengan Hybrid Learning melalui Moodle pada kelompok eksperimen dan pembelajaran konvensional pada kelompok kontrol. Hal ini berarti pada kedua kelompok terjadi peningkatan tetapi pada kelompok eksperimen diperoleh skor peningkatan yang lebih tinggi. Maka dapat disimpulkan bahwa pembelajaran dengan Hybrid Learning melalui Moodle lebih baik dalam meningkatkan hasil belajar siswa.

Peningkatan yang signifikan pada kelompok eksperimen dikarenakan dalam pembelajaran di kelas selama pengamatan, guru menerapkan prinsip dari Hybrid Learning melalui Moodle, yaitu berkaitan dengan prinsip otonomi kegiatan siswa dimana dalam pembelajaran di kelas, guru menghargai dan membiarkan siswa untuk menemukan sendiri konsep-konsep sehingga siswa dapat menyimpan lebih lama konsep-konsep tersebut dalam memori mereka. Memang penerapan prinsip penemuan terbimbing tidak begitu maksimal dilaksanakan, tapi guru berusaha agar siswa dapat melakukan semua langkah-langkah penemuan dengan sedikit bimbingan dari guru sehingga siswa lebih memahami konsep-konsep yang telah ditemukannya sendiri tersebut.

Berdasarkan hasil penelitian tentang hasil belajar siswa tersebut, maka secara umum dapat dikatakan bahwa siswa yang pembelajarannya dengan Hybrid Learning melalui Moodle menunjukkan hasil peningkatan yang lebih baik dibanding pembelajaran secara konvensional. Hal ini dimungkinkan karena pembelajaran telah berubah dari paradigma pembelajaran yang berpusat pada guru kepada pembelajaran yang menekankan pada keaktifan siswa untuk mengkonstruksi pengetahuannya sendiri melalui tantangan masalah, aktivitas penemuan, dan kerja dalam kelompok kecil ataupun diskusi kelas. Kondisi ini diperkuat oleh pendapat Suryadi (2005) yang menyatakan bahwa dengan terjadinya interaksi antar siswa akan diperoleh banyak keuntungan, antara lain sharing pengetahuan dan pendapat, refleksi atas 
hasil pemikiran masing-masing, dan akhirnya akan bermuara pada peningkatan pemahaman untuk masing-masing anggota kelompok. Sejalan dengan ini, pendapat yang dikemukakan oleh Tyler (Wassahua, 2009) bahwa pengalaman atau pembelajaran dapat memberikan kesempatan kepada peserta didik untuk memperoleh keterampilan-keterampilan dalam menemukan konsep, sehingga kemampuan berpikir dan bernalar dapat dikembangkan.

Menurut Shimada (Wassahua, 2009) bahwa pengembangan pengetahuan dan kemampuan yang diperoleh siswa sebagai komponen dari tujuan lebih tinggi bergantung tidak hanya pada bakat asli tapi juga secara signifikan dipengaruhi oleh bagaimana guru bisa mengembangkan pola pembelajarannya atau memperbaiki cara pengajaran yang selama ini kurang memperhatikan bakat dan kemampuan siswa serta perlu lebih banyak memberikan bimbingan dan motivasi kepada siswa.

Selanjutnya menurut Turmudi (Wassahua, 2009) mengemukakan bahwa untuk memberikan dukungan wacana kelas secara lebih efektif, guru harus membangun masyarakat di mana siswa merasa bebas mengemukakan gagasannya. Oleh karena itu, bantuan guru sangat diharapkan dan diperlukan agar diskusi dan tukar pikiran dapat berjalan lancar sehingga gagasan yang dikemukakan siswa dapat dipahami oleh temannya yang lain. Hal ini terlihat pada proses pembelajaran yang berlangsung di kelas di mana guru menciptakan suasana kelas dengan membentuk kelompok kecil untuk berdiskusi. Dengan demikian siswa bisa secara bebas menyampaikan ide dan gagasan yang ada pada dirinya untuk lebih dikembangkan.

Memang diakui oleh guru bahwa metode ini adalah sesuatu hal yang baru bagi mereka, sehingga pada awal pembelajaran siswa dan bahkan guru masih bingung dalam mempraktekkannya. Hal ini terlihat dari pertemuan pertama yang belum berjalan dengan baik, namun pada pertemuan selanjutnya pembelajaran mulai berjalan dengan baik sesuai dengan yang diharapkan, aktivitas siswa sudah memperlihatkan kemajuan mulai dari aktivitas penemuan hingga akhirnya siswa dapat mempresentasikan hasil temuannya di depan kelas.

\section{KESIMPULAN}

Berdasarkan hasil penelitian, dapat diambil kesimpulan bahwa Pelaksanaan Hybrid Cooperative Learning dalam pembelajaran di SMA Provinsi Riau pada mata pelajaran matematika termasuk kategori tinggi demikian juga halnya pada mata pelajaran sosiologi; aktivitas siswa dalam pembelajaran Hybrid Coperative Learning di SMA Provinsi Riau lebih baik dan aktivitas siswa pada mata pelajaran sosiologi lebih tinggi daripada mata pelajaran matematika. Hal ini ditunjukkan nilai mean mata pelajaran sosiologi lebih tinggi daripada mean mata pelajaran matematika; sikap belajar siswa dalam pembelajaran Hybrid Coperative Learning di SMA Provinsi Riau memiliki respon positif dari seluruh siswa baik pada mata pelajaran matematika maupun pada mata pelajaran sosiologi; hasil belajar siswa dalam pembelajaran Hybrid Coperative Learning di SMA Provinsi Riau mengalami peningkatan yang cukup signifikan. Hal ini ditunjukkan dari nilai peningkatan nilai 
setiap siswa; terdapat perbedaan hasil belajar siswa antara yang belajar dengan metode Hybrid Coperative Learning dan siswa yang belajar dengan metode konvensional di SMA Provinsi Riau.Perbedaan tersebut dipertegas lagi dengan nilai mean kelas eksperimen 36,663 sedangkan mean kelas control 33,078. Hasil perhitungan ini menunjukkan bahwa kemampuan siswa kelas eksprimen lebih baik daripada siswa kelas kontrol. Ini berarti nilai kelas eksperimen lebih baik; terdapat perbedaan hasil belajar siswa antara mata pelajaran Matematika dan mata pelajaran sosiologi yang diajar dengan Hybrid Cooperative Learning di SMU Provinsi Riau. Perbedaan tersebut dipertegas lagi dengan nilai mean mata pelajaran matematika 28,905 sedangkan mean sosiologi 43,588. Hasil perhitungan ini menunjukkan bahwa mata pelajaran sosiologi lebih baik daripada matematika. Ini berarti mata pelajaran sosiologi lebih baik dengan menggunakan Hybrid Learning melalui moodle; terdapat perbedaan hasil belajar siswa antara Kota dan Semi-Kota yang diajar dengan Hybrid Cooperative Learning di SMU Provinsi Riau.Perbedaan tersebut dipertegas lagi dengan nilai mean kota 39,291 sedangkan mean semi kota 33,203. Hasil perhitungan ini menunjukkan bahwa kota lebih baik daripada semi kota. Ini berarti kota lebih baik; terdapat perbedaan hasil belajar siswa antara SMAN 1 Pekanbaru, SMAN 1 Dumai, SMAN 1 Siak dan SMAN 1 Tembilahan Hulu dengan Hybrid Cooperative Learning di SMU Provinsi Riau; dan sekolah yang memiliki peranan menyebabkan terjadi perbedaan yang signifikan di empat sekolah adalah SMA Negeri 1 Tembilahan.

\section{DAFTAR PUSTAKA}

Freire,P. (1984). , Pendidikan sebagai Praktek Pembebasan, Alih bahasa: Alois A. Nugroho. Jakarta : PT Gramedia, 1984.

Hartono. (2010). Statistik Untuk Penelitian. Yogyakarta: Pustaka Pelajar.

Hwang, G.J, Wu, C.H and Kuo, F.R. (2013). Joernal of Educational Technology and Society, Vol. 16, No.3. Effects of Touch Technology-based Concept Mapping on Students' Learning Attitudes and Perceptions

Kodijat. A, M. (2001). On-line Services pada Industri Pendidikan. [Online]. Tersedia : http://www.ristek.go.id/berita/ardito. htm. 2001

Nirmala. (200) . Pembelajaran Matematika dengan Pemecahan Masalah untuk Meningkatkan Kemampuan Pemahaman dan Komunikasi Matematika Siswa Sekolah Dasar. Tesis UPI Bandung. [Tidak Diterbitkan].

Sari, D. (2009). Tempo. Pustekkom Ingatkan Pemanfaatan Internet di 18 ribu Sekolah. [Online]. Tersedia http://www.tempointeraktif.com/hg/pendidikan/2009/12/27/brk,20091227215818,id.html, 2009. [Januari 2010]. 
Slavin, R.E. (2008). Cooperative Learning: Teori dan Praktik. Bandung: Nusa Media.

Suara Pembaharuan. (2009). [Online]. Tersedia : http://www.suarapembaruan.com/News/2009/08/22/index.html. [Januari 2010].

Suhartanto,H. (2010). Journal of Information Systems. Vol. 6, Issues 1, 201. Survei 2009: Mutu Situs e-Learning Sekolah Indonesia Masih Sangat Minim.

Suherman, E, dkk. (2011). Strategi Pembelajaran Matematika Kontemporer. Bandung : FMIPA UPI.

Soekartawi. (2003). Prinsip Dasar E-Learnig : Teori dan Aplikasinya di Indonesia. Jakarta : Teknodik.

Suryadi. (2005). Penggunaan Pendekatan Pembelajaran Tidak Langsung serta Pendekatan Gabungan Langsung dan Tidak Langsung dalam Rangka Meningkatkan Kemampuan Berfikir Matematika Tingkat Tinggi Siswa SLTP. Disertasi UPI Bandung. [Tidak Diterbitkan].

Zaini, H. et.al. (2008). Strategi Pembelajaran Aktif. Yogyakarta: Pustaka Insan Madani.

Wassahua. (2009). Pembelajaran Matematika Melalui Pendekatan Open-Ended untuk Meningkatkan Kemampuan Berpikir Kritis dan Komunikasi Matematik Siswa Sekolah Dasar. Tesis UPI Bandung. [Tidak Diterbitkan]. 